\title{
Effects of nanosuspension and inclusion complex techniques on the in vitro protease inhibitory activity of naproxen
}

\author{
Senthil Rajan Dharmalingam*, Kumarappan Chidambaram, Srinivasan Ramamurthy, \\ Shamala Nadaraju
}

School of Pharmacy, International Medical University, Bukit Jalil, Kuala Lumpur, Malaysia

\begin{abstract}
This study investigated the effects of nanosuspension and inclusion complex techniques on in vitro trypsin inhibitory activity of naproxen - a member of the propionic acid derivatives, which are a group of antipyretic, analgesic, and non-steroidal anti-inflammatory drugs. Nanosuspension and inclusion complex techniques were used to increase the solubility and anti-inflammatory efficacy of naproxen. The evaporative precipitation into aqueous solution (EPAS) technique and the kneading methods were used to prepare the nanosuspension and inclusion complex of naproxen, respectively. We also used an in vitro protease inhibitory assay to investigate the anti-inflammatory effect of modified naproxen formulations. Physiochemical properties of modified naproxen formulations were analyzed using UV, IR spectra, and solubility studies. Beta-cyclodextrin inclusion complex of naproxen was found to have a lower percentage of antitryptic activity than a pure nanosuspension of naproxen did. In conclusion, nanosuspension of naproxen has a greater anti-inflammatory effect than the other two tested formulations. This is because the nanosuspension formulation reduces the particle size of naproxen. Based on these results, the antitryptic activity of naproxen nanosuspension was noteworthy; therefore, this formulation can be used for the management of inflammatory disorders.
\end{abstract}

Uniterms: Naproxen/nanosuspension/anti-inflammatory activity. Naproxen/inclusion complex/antiinflammatory activity. Naproxen/solubility. Protease inhibition.

O objetivo do presente estudo foi investigar a atividade anti-inflamatória in vitro de nanossuspensões e do complexo de inclusão contendo naproxeno. Esse fármaco é derivado de ácido propiônico, com ação analgésica, antipirética e antiinflamatória. A obtenção dessas formulações teve por finalidade o aumento da solubilidade e da atividade anti-inflamatória do fármaco. Os métodos por precipitação em solução aquosa por evaporação e por empastagem foram modificados para a obtenção da nanossuspensão e do complexo de inclusão, respectivamente. Para a avaliação da atividade anti-inflamatória das formulações utilizou-se ensaio in vitro modificado de inibição de tripsina. As propriedades físico-químicas das formulações propostas foram determinadas utilizando espectroscopia UV e de infravermelho, além de estudos de solubilidade. $\mathrm{O}$ complexo de inclusão de naproxeno apresentou menor atividade antitripsina, quando comparado ao composto livre e à nanossuspensão. Em conclusão, entre as formulações avaliadas, a nanossuspensão de naproxeno apresentou maior efeito anti-inflamatório. Esse efeito foi devido à redução da dimensão das partículas de naproxeno para a escala nanométrica. Com base nos resultados obtidos, a atividade da nanossuspensão de naproxeno foi notável. Dessa forma, essa formulação apresenta potencial para o tratamento de distúrbios inflamatórios.

Unitermos: Naproxeno/nanossuspensão/atividade anti-inflamatória. Naproxeno/complexo de inclusão/ atividade anti-inflamatória. Naproxeno/solubilidade. Inibição da protease.

\section{INTRODUCTION}

Naproxen is a stereochemically pure (dextrorotary isomer of 6-methoxy- $\alpha$-methyl-2-naphthalene acetic acid)

\footnotetext{
*Correspondence: S. R. Dharmalingam. School of Pharmacy, International Medical University, Bukit Jalil, Kuala Lumpur, Malaysia. E-mail: dsenthilrajan@yahoo.co.in
}

no steroidal anti-inflammatory drug of the 2-arylpropionic acid class (Davies, Anderson, 1997). In humans, it is oxidised to 6-O-desmethylnaproxen, and both the parent drug and metabolite are conjugated as acyl glucuronides (Todd, Clissold, 1990). Naproxen has been extensively used during the past decades in the treatment of rheumatoid arthritis, febrile syndrome, and pain (Davies, Anderson, 1997). Naproxen, like most 
other non-steroidal anti-inflammatory agents, inhibits prostaglandin synthesis and thromboxanes (Vane, 1971). Both PGE2 and PGI2 markedly enhance edema formation and leukocyte infiltration by promoting blood flow in an inflamed region. Systemic inhibition of COX leads to decreased production of PGs at inflammation sites and in the spinal cord. Naproxen is also indicated to relieve the signs and symptoms of tendonitis, bursitis, and acute gout, as well as to manage pain and primary dysmenorrhea. The inhibition of COX-2 is mainly thought to mediate the antipyretics, analgesic, and anti-inflammatory action of naproxen (Setiawati et al., 2009). However, the naproxen action mechanism is not completely understood. It is a very potent member of the propionic acid derivatives, which represent a group of effective, useful antipyretic, analgesic, and non-steroidal anti-inflammatory drugs.

There have not been many strategies to enhance the solubility of naproxen. Polyoxyethylene esters as dermal prodrugs (Bonina et al., 2001), acyloxyalkyl esters (Rautio et al., 1998), and supramolecular carrier systems (Hector et al., 2007) with naproxen have been reported.

Proteases are involved in many essential intracellular and extracellular physiological processes, but their critical role in the development of diseases is also well established. Recent developments in the field of proteinase have led researchers to inquire closely into their exact biological functions. There is now substantial evidence that certain proteases can regulate target cells by cleaving and activating a family of G-protein-coupled, proteaseactivated receptors (PARs). Potential roles for PARs in inflammation have also been proposed. For example, because platelets can produce inflammatory mediators, such as serotonin and chemokines, platelet activation by thrombin through PAR1 might amplify inflammatory responses or recruitment of inflammatory cells (Coughlin, 2000). These potential pro-inflammatory effects of trypsinlike proteases raise two important questions - whether and how these proteases affect inflammatory cell functions (Lee et al., 1984). Therefore, proteases are perhaps the largest class of enzymes to be used as targets for structurebased drug design. Recent studies have demonstrated that protease inhibitors may have anti-inflammatory roles other than mere suppressive effects on protease actions during inflammation. Currently, trypsin is used routinely for preparing keratinocyte cultures from epidermal sheets or for splitting confluently grown cells in vitro. In vivo, trypsin, and other fecal enzymes cause skin irritation and may play an etiologic role in perianal, circumstomal, and diaper dermatitis. The hallmarks of these diseases are inflammation and epidermal hyperproliferation. In an earlier study, we raised the question of whether trypsin, as an exemplary serine protease capable of activating PAR-2 (and in higher concentrations, PAR-1), induces epidermal changes (Meyer-Hoffert et al., 2004). Therefore, this investigation sought to assess the effects of nanosuspension and inclusion complex techniques on the in vitro protease inhibitory activity of naproxen.

\section{MATERIAL AND METHODS}

\section{Drugs and Chemicals}

Naproxen (Ezo Life Sciences, CAS 22204-53-1), carboxymethyl cellulose (CMC), hydroxypropylmethyl cellulose (HPMC), poly(vinyl alcohol) (PVA), methanol, ethyl acetate, sodium chloride, disodium hydrogen phosphate, trypsin, tris hydrochloride (Tris-C1), casein, triethanolamine, cellulose nitrate membrane, and isopropyl myristate were supplied by Sigma-Aldrich. All other chemicals and solvents used were commercially available products of analytical grade. A Shimadzu UV-1800 UV/ VIS spectrophotometer was used with a $1 \mathrm{~cm}$ match quartz cell, and a CP224S analytical balance (Sartorius) and ultrasonic cleaner (Fisher Scientific FB15061) were used. A micropipette with a variable volume of $10-1000 \mu \mathrm{L}$ (Capp Ecopipette single channel) and a digital balance (Mettler Toledo XP 105) were also used.

\section{EPAS Preparation of the Nanosuspension}

The Evaporative Precipitation into Aqueous Solution (EPAS) technique was used to produce a nanoparticle suspension of naproxen. When a heated organic solution of the drug is sprayed though a fine nozzle into a heated aqueous solution, the rapid evaporation of the organic solvent produces high supersaturation and rapid precipitation of the drug in the form of a colloidal suspension that is stabilized by a variety of low molecular weight and polymeric surfactants. The stabilizer adsorbs to the drug surface and prevents particle growth and crystallization during the spraying process (Chen, 2002; Sarkari, 2002). A weighed amount of naproxen was dissolved in $10 \mathrm{~mL}$ of ethyl acetate. The resultant solution is then sprayed though a fine nozzle into a heated aqueous solution at $80-85^{\circ} \mathrm{C}$ containing stabilizing surfactant and polysorbate 80 . The mixture is then continuously stirred magnetically. Ethyl acetate is allowed to evaporate forming the nanosuspension. The rapid evaporation of the organic solvent produces high supersaturation and rapid precipitation of the drug in the form of a colloidal suspension. Last, the colloidal suspension is centrifuged and freeze dried. 


\section{Preparation of Inclusion Complex by the Kneading Method}

A weighed quantity of $\beta$-cyclodextrin $(\beta-C D)$ was mixed with a minimum quantity of distilled water in a mortar to obtain a homogeneous paste. A weighed quantity of naproxen powder was then slowly added. After that, the mixture was ground for 1 hour. During this process, an appropriate quantity of water was added to the mixture to maintain a pasty consistency. The whole procedure was carried out at room temperature. The paste was then oven dried at $45^{\circ} \mathrm{C}$ for 24 hours. The dried complex was pulverized, and it then was passed through a \#100 sieve and stored in a desiccator over fused calcium chloride pending further study. The complexes were prepared in both 1:1 and 1:2 molar ratios (Sapkal et al., 2010).

\section{UV Analysis}

The maximum absorption value for the naproxen was found to be $331 \mathrm{~nm}$ using the UV spectrophotometric method. The linear regression equation obtained by the least square regression method was $\mathrm{y}=0.0108 \mathrm{X}-0.028$ with a correlation coefficient of 0.9984 where $y$ is the absorbance and $\mathrm{x}$ is the concentration of the pure naproxen solution. The method was validated for several parameters such as linearity, accuracy (recovery), precision, and specificity under the International Conference on Harmonization $(\mathrm{ICH})$ guidelines. The limits of detection (LOD) and quantification (LOQ) were $1.53 \mu \mathrm{g} / \mathrm{mL}$ and $5.11 \mathrm{mg} / \mathrm{mL}$, respectively.

\section{Solubility Determination}

The solubility of pure naproxen, nanosuspension of naproxen, and inclusion complex with a 1:2 molar ratio (a $50 \mathrm{mg}$ equivalent amount ) were analysed by adding naproxen to $10 \mathrm{~mL}$ of each fluid in a $25 \mathrm{~mL}$ stopped conical flask after which the mixtures were shaken for 24 hours at room temperature $\left(25 \pm 1^{\circ} \mathrm{C}\right)$ on a rotary shaker. After 24 hours of shaking, $2 \mathrm{~mL}$ aliquots were withdrawn at two-hour intervals and immediately filtered using a $0.45 \mu$ disk filter. The filtered samples were diluted suitably and analysed by a UV UV/VIS spectrophotometer at $331 \mathrm{~nm}$. Each solubility experiment was replicated three times $(n=3)$ (Chowdary, Surya Prakasa Rao, 2011).

\section{Infrared (IR) Spectra for Cyclodextrin Inclusion Complex}

Studies were done by Fourier using infrared spectroscopy (FTIR-8300, Shimadzu Co., Kyoto, Japan) and scanned against a blank $\mathrm{KBr}$ pellet background at a wave number ranging from 4000 to $650 \mathrm{~cm}^{-1}$ with a resolution of $1.0 \mathrm{~cm}^{-1}$ (Sapkal et al., 2010).

\section{In vitro Protease (Trypsin) Inhibitory Activity}

The antitryptic activity of the pure naproxen, nanosuspension of naproxen, and inclusion complex with a 1:2 molar ratio were assayed by the method previously described (Anantha et al., 1956). The reaction mixture $(2.0 \mathrm{~mL})$ contained $0.06 \mathrm{~mL}$ trypsin $(0.6 \mu \mathrm{g})$, varying volumes of modified naproxen formulations, and a $25 \mathrm{mM}$ Tris-C1 buffer, $\mathrm{pH}$ 7.5. The mixture was incubated at $37^{\circ} \mathrm{C}$ for 5 minutes. Then, $1 \mathrm{~mL}$ of $0.8 \%(\mathrm{w} / \mathrm{v})$ casein was added. The mixture was incubated for an additional 20 minutes and $2 \mathrm{~mL}$ of $2 \mathrm{M} \mathrm{HClO}_{4}$ were added to terminate the reaction. The cloudy suspension was clarified by centrifugation and the absorbance of the supernatant was read at $280 \mathrm{~nm}$ against the buffer as blank.

\section{RESULTS AND DISCUSSION}

\section{FTIR Spectra Analysis}

Characteristic peaks at $1820-1670 \mathrm{~cm}^{-1}$ were observed due to the presence of $\mathrm{C}=\mathrm{O}$ stretching, which is the important characteristic of naproxen (Figure 1.a). This suggested that the aromatic structure (non-polar) of naproxen is entrapped inside the cyclodextrin cavity while the carboxylic acid group still remains outside the cyclodextrin cavity. Hence, $\mathrm{C}=\mathrm{O}$ stretching at $1728 \mathrm{~cm}^{-1}$ is observed in the IR spectra of the inclusion complex (Figures 1 and 2).

\section{Solubility studies}

The solubility profile of pure naproxen, nanosuspension, and naproxen-cyclodextrin complex is shown in Figure 3. The solubility using beta-cyclodextrin techniques is better than that using the nanosuspension technique. $\beta$-Cyclodextrin inclusion complex of naproxen in a 1:2 ratio showed the highest percentage of dissolved drug, which was 10 times higher than plain naproxen, while the solubility nanosuspension technique is 3 times higher than that for plain naproxen. The increased surface area and concentration gradient lead to a much more pronounced increase in the solubility of nanosuspension as compared to that for a pure drug. The diffusional distance of drug nanoparticles on the surface is decreased, thus leading to an increased concentration gradient (Muller, Peters, 1998). 

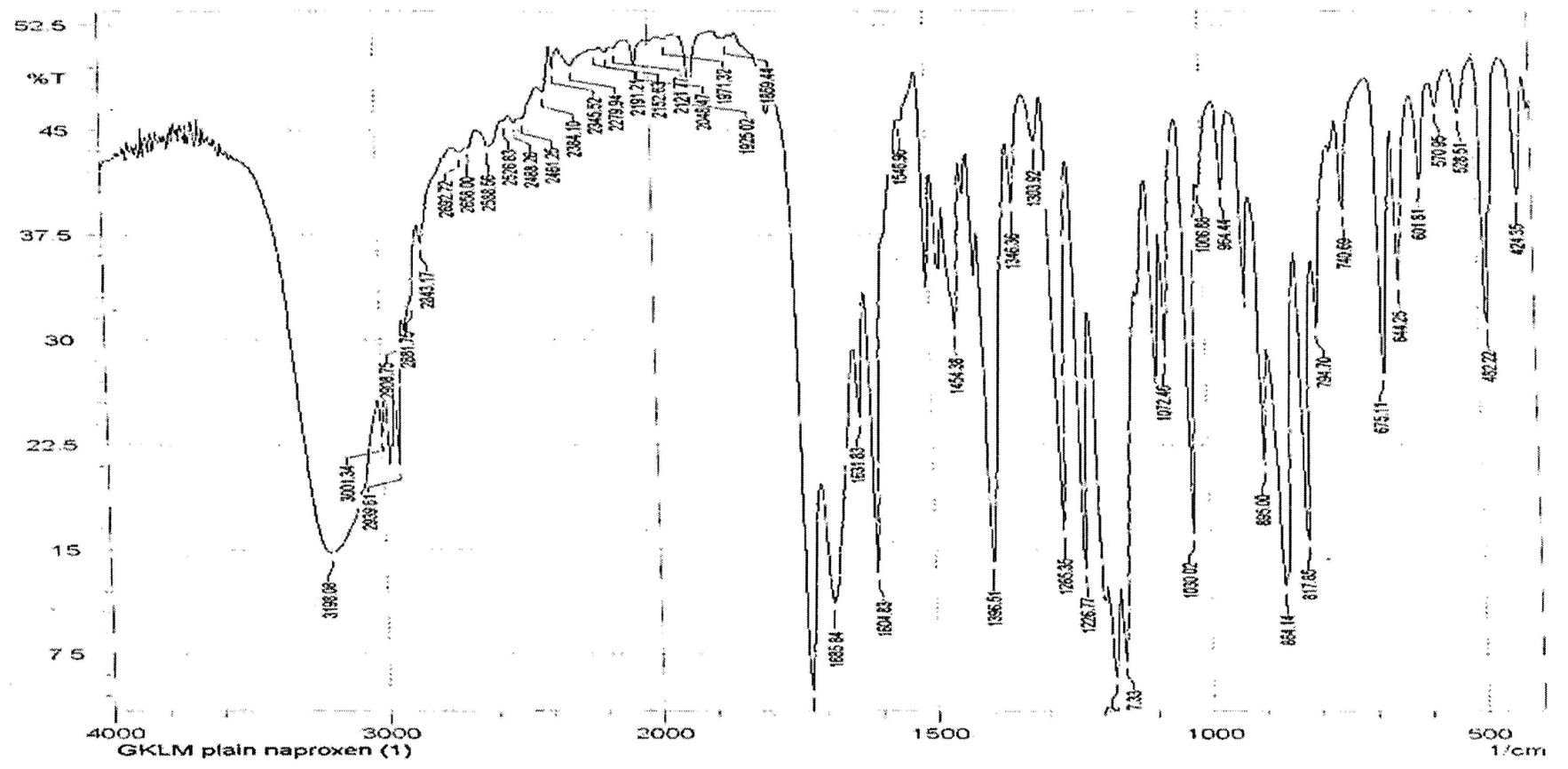

FIGURE 1 - IR spectra of plain naproxen.

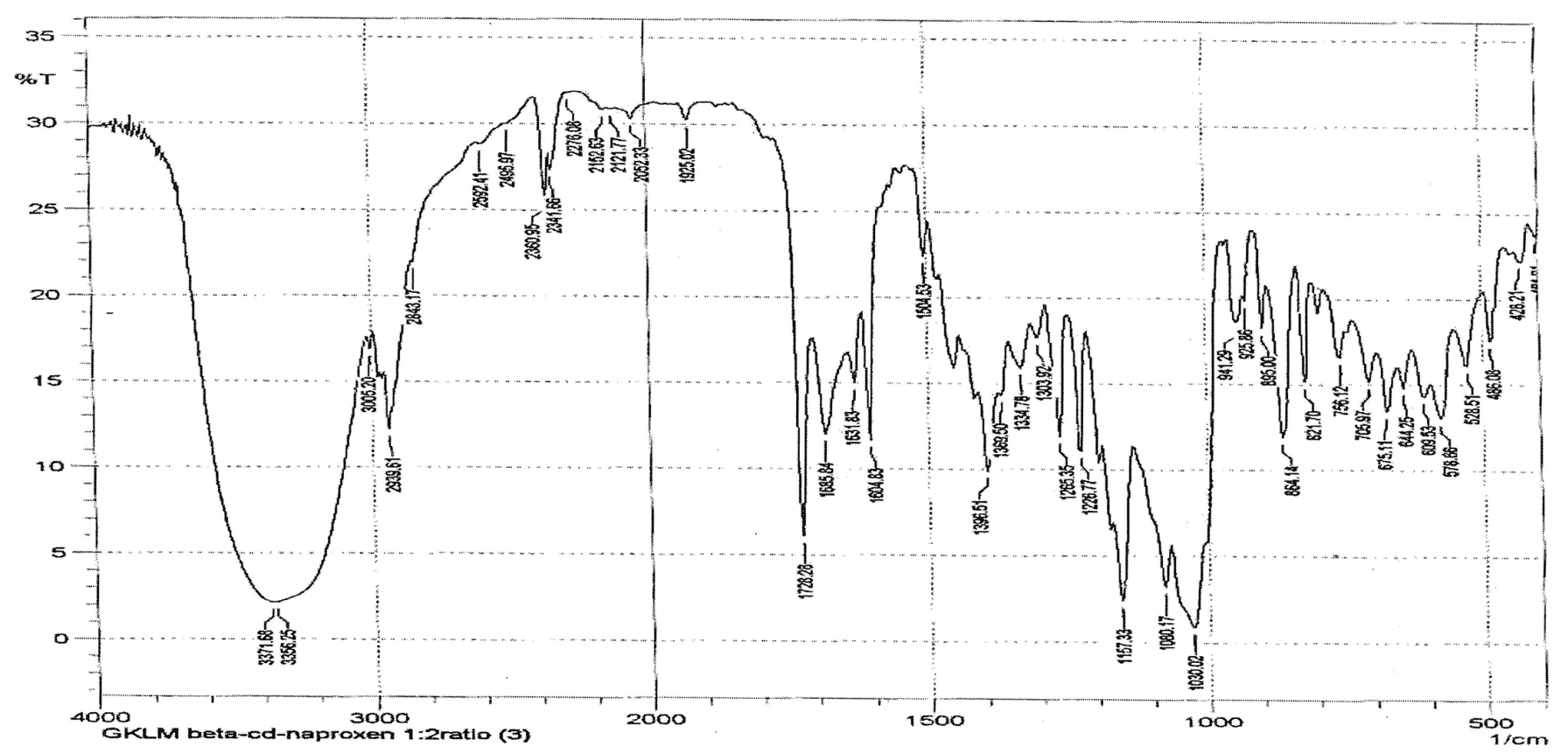

FIGURE 2 - IR spectra of naproxen-cyclodextrin complex.

\section{Anti-protease inhibitory activity}

Proteases have been implicated in tumourigenesis, invasive growth, alteration of cellular surface charges, and the release of cells from density-dependent inhibition (Techesche et al., 1974). Conversely, removal of protease activity from the sites of inflammation or blockade of eosinophil PARs may benefit patients with allergic diseases by dampening this vicious cycle of allergic inflammation. Recent studies have demonstrated that protease inhibitors may have anti-inflammatory roles other than mere suppressive effects on protease actions during inflammation. A number of mediators, including lipid mediators, cytokines, free radicals, complement fragments, coagulatory factors, and proteases contribute to the pathogenesis of endotoxin shock (Bhole, Stahl, 
2003). Among them, the products from neutrophils are recognized to play important roles. Activated neutrophils release various kinds of mediators, including proteases and oxygen radicals (Weiss, 1989). The proteases produced by neutrophils can be a key mediator of tissue injury (Travis, 1988). Protease-antiprotease imbalance has been involved in a variety of inflammatory diseases (Chapman et al., 1997; Deng et al., 2001).

It is also evident that the inclusion complex method exhibits a higher solubility profile than nanosuspension and the plain drug do (Figure 3). This enhancement has been attributed in all these cases both to the formation of an inclusion complex in the solid state and to the reduction of the crystalinity of the products.

The trypsin inhibitory effect of naproxen and its modified formulations is shown in Figure 4. Universally, naproxen has established anti-inflammatory effects. It is a trypsin inhibitor that acts as a competitive analog and binds with its serine protease to form an inactive complex, rendering the protease inactive, thus acting as an antiinflammatory agent (Reddy et al., 2003; Caramori et al., 2004). The two modified formulations and pure naproxen exhibited varying degrees of trypsin inhibitory activity. Nanosuspension of naproxen exhibit the highest antitryptic

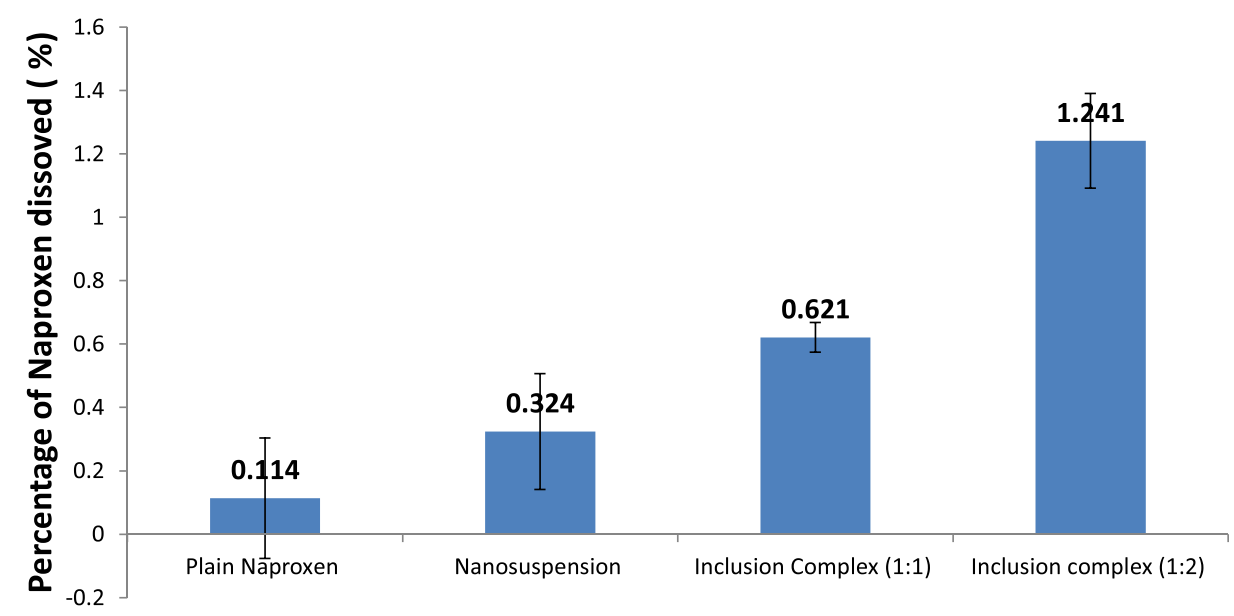

FIGURE 3 -The solubility of different naproxen formulations in distilled water. Values are expressed as the mean \pm SEM of triplicate experiments.

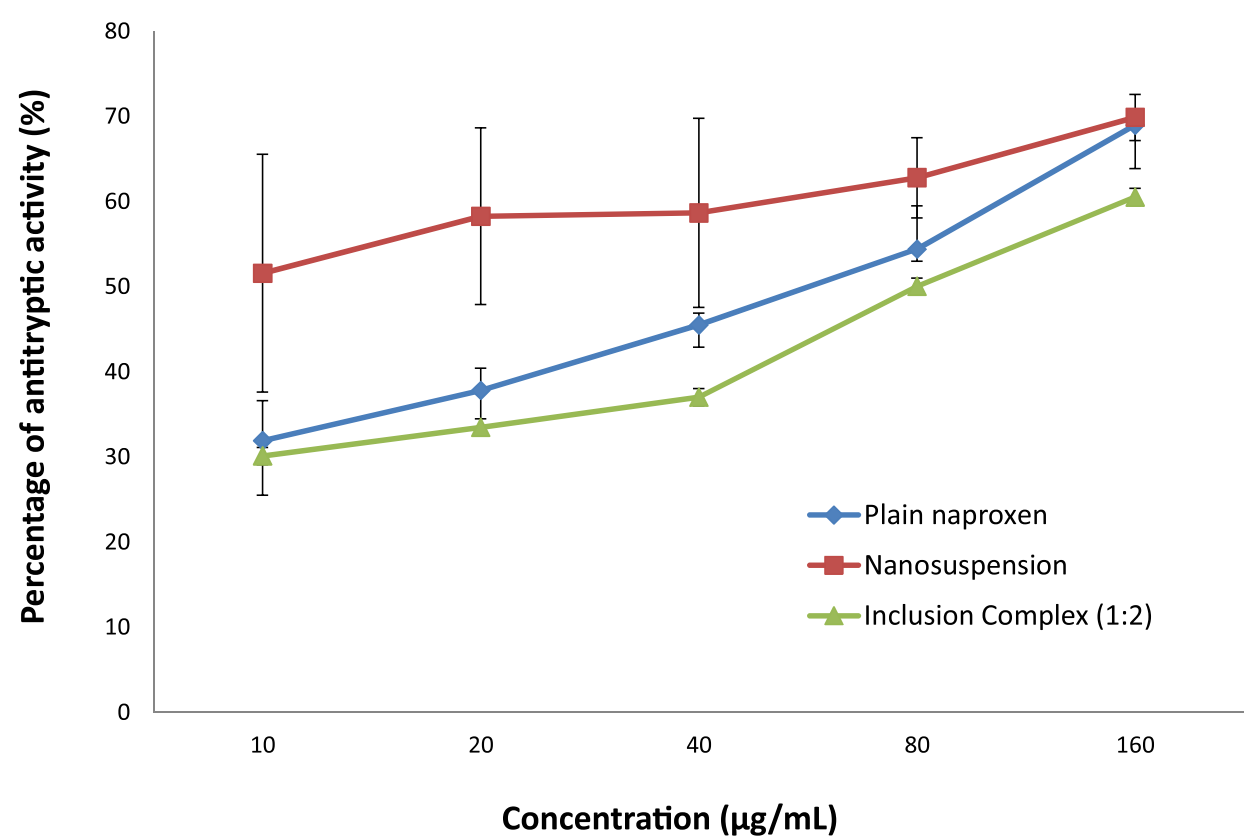

FIGURE 4 -In vitro antitryptic activity of different naproxen formulations. Values are expressed as the mean \pm SEM of triplicate experiments. 
activity, which was 1.5 times higher than that of plain naproxen. This suggested that nanosuspension of naproxen has greater anti-inflammatory effect than the other formulations. The antitryptic effects of nanosuspension are significantly different from those of plain naproxen. In nanosuspension, the reduced particle size of naproxen will increase the surface area and number of particles. In turn, this will lead to more extensive antitryptic activity as more trypsin breaks down due to its enhanced solubility profile compared to that of plain naproxen. However, $\beta$-cyclodextrin inclusion complex showed the lowest antiinflammatory activity when compared to the inclusion complex formulation, which was encapsulated in the cavity of $\beta$-cyclodextrin and unable to interact with trypsin to form an inactive naproxen-trypsin complex responsible for an anti-inflammation reaction.

Poor solubility can be partly attributed to hydrophobicity as evidenced by poor wetting of the drug surface. This causes the particles to aggregate rather than disperse. The solubility profile in the nanosuspension was improved because of the increased surface area, which enhances the strong hydrophilic character of the drug toward polysorbate 80 . This is because of the formation of intermolecular hydrogen bonds and improved wettability of hydrophobic naproxen. Saturation solubility is compound specific constant depending upon temperature and the properties of the dissolution medium.

$\beta$-Cyclodextrin inclusion complex of naproxen has a lower percentage of antitryptic activity than both plain naproxen and nanosuspension of naproxen. Nevertheless, the difference of antitryptic activity between betacyclodextrin inclusion complex of naproxen and plain naproxen is not significant when the $\mathrm{p}$ value is greater than 0.05 . Hence, this result shows that beta-cyclodextrin inclusion complex does not increase the anti-inflammation activity of naproxen. This suggests that the large molecules of the inclusion complex were unable to form an inactive complex with trypsin, which in turn reduced the inhibitory effect of naproxen towards trypsin. Thus, it does not improve the anti-inflammatory effect of naproxen. In conclusion, nanosuspension naproxen has greater antiinflammatory effect than the other two formulations. This is because the nanosuspension formulation has reduced the particle size of naproxen, thus increasing the surface area and number of naproxen particles. Hence, this leads to a greater extent of anti-proteolytic activity.

\section{CONCLUSION}

The Nanosuspension and inclusion complex technique were prepared and showed that they better enhance solubility in comparison to pure naproxen's solubility. Based on these results, the antitryptic activity of naproxen nanosuspension was noteworthy. These findings appear to justify the nanosuspension of naproxen in the management and treatment of inflammation-associated ailments. The new formulation based on the nanosuspension technique can be adapted to enhance solubility and the antitryptic activity of drugs with poor water solubility.

\section{REFERENCES}

ANANTHASAMY, T.S.; NATARAJAN, S.; CAMA, H.R. Physiochemical and biological properties of glycoproteins isolated from the plasma of different species of animals. Biochem. J., v.96, p.281-288, 1965.

BHOLE, D.; STAHL, G.L. Therapeutic potential of targeting the complement cascade in critical care medicine. Crit. Care Med., v.31, suppl.1, p.S97-S104, 2003.

BONINA, F.P.; PUGLIA, C.; BARBUZZI, T.P.; DE CAPRARIIS, F.; PALAGIANO, M.G.; RIMOLI SAIJA, A. In vitro and in vivo evaluation of polyoxyethylene esters as dermal prodrugs of ketoprofen, naproxen and diclofenac. Eur. J. Pharm. Sci., v.14,p.123-134, 2001.

CARAMORI, S.S.; LIMA, C.S.; FERNANDES, K.F. Biochemical characterization of selected plant species from Brazilian savannas. Braz. Arch. Biol. Techn., v.47, p.253-259, 2004.

CHAPMAN, H.A.; RIESE, R.J.; SHI, G.P. Emerging roles for cysteine proteases in human biology. Annu. Rev. Physiol., v.59, p.63-88, 1997.

CHEN, X.; YOUNG, T.J.; SARKARI, M.; WILLIAMS, R.O.; JOHNSTON, K.P. Int. J. Pharm., v.242, p.3-14, 2002.

CHOWDARY, K.P.R.; SURYA PRAKASA RAO, K. Factorial studies on the effects of $\beta$ - cyclodextrin and poloxamer 407 on the solubility and dissolution rate of BCS class II drugs. Int. J. Pharm. Res. Dev., v.3, p.125-130, 2011.

COUGHLIN, S.R. Thrombin signalling and protease-activated receptors. Nature, v.407, p.258, 2000.

DAVIES, N.M.; ANDERSON, K.E. Clinical pharmacokinetics of naproxen. Clin. Pharmacokinet.,v.32, p.268-293, 1997. 
DENG, X.; WANG, X.; LASSON, A.; SUN, T.Z.; SOLTESZ, V.; ANDERSSON, R. The involvement of multiple proteaseantiprotease systems and gut origin sepsis in zymosanassociated endothelial barrier injury and multiple organ dysfunction in rats. Shock, v.16, p.298-303, 2001.

HECTOR L.R.; AYMARA, V.; ROBERTO, C.; ALEX, F.; JUAN JOSE, T.L.; MAYSA, B.; REYNALDO, V. Preparation of $\beta$-cyclodextrin-dextran polymers and their use as supramolecular carrier systems for naproxen. Polym. Bull.,v.59, p.597-605, 2007.

INOUE, K.; TAKANO, H.; SHIMADA, A.; YANAGISAWA, R.; SAKURAI, M.; YOSHINO, S.; SATO, H.; YOSHIKAWA, $\mathrm{T}$. Urinary trypsin inhibitor protects against systemic inflammation induced by lipopolysaccharide. Mol. Pharmacol., v.67, p.673-680, 2005.

INTERNATIONAL CONFERENCE ON HARMONISATION. Harmonized tripartite guidelines. Stability testing of new drug substances and products. ICH Committee, v.68, p.65717-65718, 2003. Available at: www.ich.org/fileadmin/ Public_Web_Site/ICH_Products/Guidelines/Quality/ Q1A_R2/Step4/Q1A_R2_Guideline.pdf. Accessed on: 23 Aug. 2012.

LEE, T.; LENIHAN, D.J.; MALONE, B.; RODDY, L.L.; WASSERMAN, S.I. Increased biosynthesis of plateletactivating factor in activated human eosinophils. J. Biol. Chem., v.259, p.5526-5530, 1984.

MEYER-HOFFERT, U.; HRISTINA-ROGALSKI, C.; SEIFERT, S.; SCHMELING, G.; WINGERTSZAHN, J.; PROKSCH, E.; WIEDOW, O. Trypsin induces epidermal proliferation and inflammation in murine skin. Exp. Dermatol., v.13, p.234-241, 2004.

MIIKE, S.; MCWILLIAM, A.S.; KITA, H. Trypsin induces activation and inflammatory mediator release from human eosinophils through protease-activated receptor-2. J. Immunol., v.167, p.6615-6622, 2001.

MULLER, R.H.; PETERS, K. Nanosuspensions for the formulation of poorly soluble drug I: Preparation by size reduction technique. Int. J. Pharm., v.160, p.160, 229-237, 1998.
RAUTIO, J.; TAIPALE, H.; GYNTHER, J.; VEPSAELAEINEN, J.; NEVALAINEN, T.; JAERVINEN, T. In vitro evaluation of acyloxyalkyl esters as dermal prodrugs of ketoprofen and naproxen. J. Pharm. Sci., v.87,p.1622-1628, 1998.

REDDY, N.S.; GEURS, N.C.; GUNSOLLEY, J.C. Periodontal host modulation with antiproteinase, anti-inflammatory and bone-sparing agents. Ann. Periodontol., v.8, p.12-37, 2003.

SAPKAL, N.P.; VAISHALI, A.K.; SHEWALE, B.D.; BHUSARI, K.P.; DAUD, A.S. Study of the complexation behaviour of fexofenadine with $\beta$-cyclodextrin. Indian $J$. Pharm. Sci., v.72, p.318-323, 2010.

SARKARI, M.; BROWN, J.N.; CHEN, X.; SWINNEA, S.; WILLIAMS, R.O.; JOHNSTON, K.P. Int. J. Pharm., v.243, p.17-31, 2002.

SETIAWATI, E.; DENIATI, S.H.; YUNAIDI, D.A.; HANDAYANI, L.R.; HARINANTO, G.; SANTOSO, I.D.; PURNOMO SARI, A.; RIMAINAR, A. Bioequivalence study with two naproxen sodium tablet formulations in healthy subjects. J. Bioequiv. Availab., v.1, p.28-33, 2009.

TECHESCHE, N.; KUPFER, S.; LENGEL, O.; KLAUSER, R. Purification, characterization and structural studiesof proteinase inhibitors from boar seminal plasma and boar spermatozoa. Buyer Symposium,v.5, p.164-177, 1974.

TODD, P.A.; CLISSOLD, S.P. Naproxen- A reappraisal of its pharmacology and its therapeutic use in rheumatic diseases and pain states. Drugs, v.40, p.91-137, 1990.

TRAVIS, J. Structure, function and control of neutrophil proteinases. Am. J. Med., v.84, p.37-42, 1988.

VANE, J.R. Inhibition of prostaglandin synthesis as a mechanism of action of aspirin-like drugs. Nat. New Biol., v.231, p.232-235, 1971.

WEISS, S.J. Tissue destruction by neutrophils. N. Engl. J. Med., v.320, p.365-376, 1989.

Received for publication on $23^{\text {rd }}$ August 2012 Accepted for publication on $12^{\text {th }}$ May 2013 
